\title{
The Systems Approach Framework as a Complementary Methodology of Adaptive Management: a Case Study in the Urban Beaches of Barcelona
}

\author{
Ben Tomlinson $^{1}, \underline{\text { Sergio Sastre }}^{1}, \underline{\text { Dolors Blasco }}^{1}$, and Jorge Guillén $^{1}$
}

\begin{abstract}
The Systems Approach Framework is a methodological framework designed to enhance the efficacy of human decision-making processes within social-ecological systems with regard to sustainability. The objective of resilience adaptive management is to either maintain the system within the current regime such that the desired ecosystem goods and services continue to be delivered, or to move the system phase to a preferred regime. Although the objectives of the two frameworks are not exactly the same, there are considerable complementarities between them. Through application of the Systems Approach Framework in a case study regarding the urban beaches of Barcelona, Spain, we present some of the main findings revealed during the model construction and stakeholder participatory process. Additionally, we demonstrate that the Systems Approach Framework could be considered a useful step-by-step methodological guide that employs many of the vital components and processes of adaptive management.
\end{abstract}

Key Words: adaptive management; Barcelona; coastal management; Spain; Systems Approach Framework; urban beach

\section{INTRODUCTION}

Social-ecological systems are under ever increasing pressure from a variety of human drivers (Millennium Ecosystem Assessment 2005a). Holling (2001) and his colleagues (Folke et al. 2002, Folke 2006, Folke et al. 2010) established a path for understanding complex social-ecological systems within a trans-disciplinary framework in which the concept of resilience is the guiding principle. Resilience of socialecological systems can be defined as the capacity of a system to absorb shocks or disturbances so that the system retains or can easily return to the same basic structure of functioning (Holling and Gunderson 2001). The aim of adaptive management (AM) as proposed by the Resilience Alliance is to either maintain the system within the current regime such that the desired ecosystem goods and services are continued to be delivered, or move the system phase to a preferred regime (Walker et al. 2002, Gunderson 2008, Chapin et al. 2009).

Coastal zones are a prime example of valuable socialecological systems under pressure (Costanza 1998, Millennium Ecosystem Assessment 2005b, Costanza and Farley 2007, Martinez et al. 2007), and following the introduction of integrated coastal zone management (King 2003) concepts, a number of methodological frameworks have been suggested to enhance the efficacy of human decisionmaking processes with regard to sustainability (European Parliament and Council 2002, McKenna and Cooper 2006). One such framework is the Systems Approach Framework (SAF) developed and tested during the four-year FP6 European Union project "Science and Policy Integration for Coastal System Assessment" (SPICOSA 2011a). The SAF was piloted in 18 different study sites (including the case presented here) in order to test the application of the methodology to a varied set of social-ecological systems, although always within the domain of coastal zones. However, it should be noted that the methodology can be applied to any social-ecological system, not only those encountered in coastal zones.

Our aim is to examine how the SAF can be complementary to and useful for AM by using a case study from Barcelona, Spain. Our hypothesis is that the SAF could work as a framework that is nested within, or is complementary to, AM applications by offering a specific step-by-step methodological guide that is useful in determined contexts.

Given that our primary objective is to compare the SAF and $\mathrm{AM}$, and due to the journal's length limitation, it is beyond the scope of this paper to analyze and comment on all the specifics of the application of the SAF in our study site. Data collection, treatment, and analysis; modeling processes; model validation; uncertainty analysis; and the complete output from the model all deserve greater analysis then we can deliver in this paper. The complete analysis of the model will be developed in additional publications. Similarly, there is insufficient space to analyze all interactions with the stakeholders, so only the key representative aspects are presented to demonstrate an example of SAF application and how it relates to AM.

Our study represents the first comparison of the SAF with a pre-existing tool for management. By doing so, we demonstrate the advantages and disadvantages of the SAF and how it compares to other decision-making frameworks.

\section{The Systems Approach Framework}

The SAF methodology is an iterative process in which continuous assessment of the relevant part of the socialecological system provides scientifically defendable information with regards to possible and probable future changes given certain scenarios. The theoretical background of the SAF is based on General Systems Theory (von Bertalanffy 1968) and Soft Systems Methodology (Checkland 
and Scholes 1990) in which model simulations of various scenarios and management options can be used to aid stakeholder engagement, thereby improving the sciencepolicy interface (SPICOSA 2011b).

The methodology contains four steps: system design, system formulation, system appraisal, and system output. There should be considerable cooperation and consultation between the relevant stakeholders (end-users, policy makers, scientists, governance agencies, other relevant institutions, and nongovernmental organizations) throughout the process.

Additional details regarding the methodology can be found in the introduction paper of this special issue (Hopkins et al. 2011), as well as in the SAF online handbook (SPICOSA 2011b) and textbook (Tett et al. 2011). Similarly, all the documentation and models regarding the application of the SAF to the Barcelona case study are provided on the SPICOSA website (SPICOSA 2011c).

\section{Adaptive management}

Adaptive management as proposed by Resilience Alliance (2007) uses management not only as a tool to change the system but also to learn about it. Key objectives of AM include making explicit underlying assumptions and identifying unknown issues. This helps reduce the use of "best guess" strategies and strengthens the link between knowledge and action (Holling and Meffe 1996, Westley 2001).

The following are considered to be vital procedural components of adaptive management:

- consideration of appropriate temporal and spatial scales

- use of computer models to build synthesis and an embodied ecological consensus

- use of embodied ecological consensus to evaluate strategic alternatives

- communication of alternatives to political arena for negotiation

- inclusion of all relevant stakeholders

- political openness

- social and scientific processes

- encouragement regarding the formation of new institutions and strategies

- enhancement of institutional flexibility (Resilience Alliance 2002)

\section{The Barcelona case study}

The large metropolitan city of Barcelona is situated in the northeast of the Iberian Peninsula and is nested between four geographical limits: the Mediterranean Sea to the east, the Serra de Collserola mountain range to the west, the River Besòs to the north, and the River Llobregat to the south.
Barcelona is the capital of Catalonia, one of the most populated autonomous communities in Spain. There are more than 1.5 million inhabitants in the city itself, but almost 5 million people live in the area directly influenced by the city. The economy is focused largely on the service sector.

Fig. 1. Coastline of Barcelona, indicating beaches, industrial harbors (1), recreational harbors (2), combined sewer overflow outlets (*), and the mouth of the River Besòs (3). (Data source: Cartographic Institute of Catalonia)

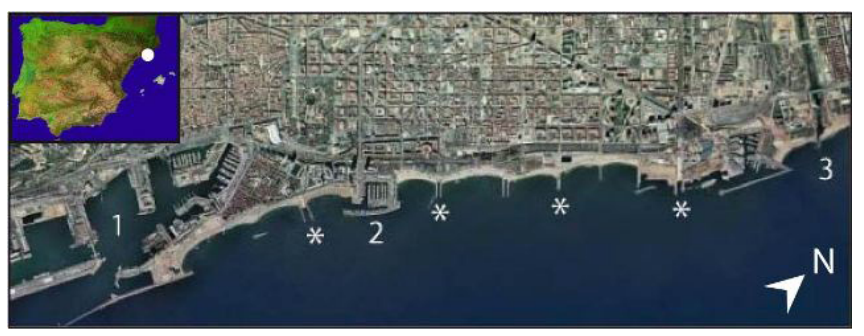

Maritime trade has been always important to the city, so the necessity of having a safe harbor has been one of the most pressing forces in changing the littoral profile of the city. Barcelona's coastline can be considered altered or artificial since the beginning of the $15^{\text {th }}$ century when the first transformations were made to enhance the protection of trade ships. The construction of dykes and breakwaters led to corresponding changes in sedimentary flows and the reclamation of almost $400 \mathrm{~m}$ of land from the sea. However, throughout the following centuries, the city has modified its relationship with the sea, and different ecosystem services have been prioritized (Novoa and Alemany 2005).

The Olympic Games in 1992 and the Universal Forum of Cultures in 2004 were two internationally recognized events that reshaped Barcelona, both figuratively as a city, and literally in terms of its coastline. The existing industrial infrastructure was replaced with artificial beaches within an urban environment, which provided a leisure space for both residents and tourists. Fishing was also of considerable economic significance, but following the industrial revolution, its importance dramatically decreased and became a marginal traditional activity (Roig 1927, Bas et al. 1955).

Whereas in the past the main ecosystem services were related to food, transport, and waste disposal, nowadays navigation, recreation, and tourism can be considered the most important services for management issues (Novoa and Alemany 2005). The large industrial harbor and the public use of beaches for leisure are the two main uses of Barcelona's urban littoral space (Fig. 1).

There is an increasing trend in the promotion of intensive-use urban artificial beaches for tourism in many large cities on the 
Table 1. List of stakeholders and meetings attended.

\begin{tabular}{|c|c|c|c|}
\hline $\begin{array}{l}\text { Scale } \\
\quad \text { Organization }\end{array}$ & Responsibilities & $\begin{array}{l}\text { Participation } \\
\text { in Systems } \\
\text { Approach } \\
\text { Framework }\end{array}$ & Issues raised by stakeholders during first meeting \\
\hline \multicolumn{4}{|c|}{ State (Spanish government) } \\
\hline $\begin{array}{l}\text { Directorate of Coasts } \\
\text { (Ministry of } \\
\text { Environment) } \\
\text { Ministry of Works }\end{array}$ & $\begin{array}{l}\text { Coastal spatial planning; public infrastructures; } \\
\text { licensing; harbor administration } \\
\text { Public Infrastructures }\end{array}$ & $\begin{array}{l}\text { Contacted: } \\
\text { attended first } \\
\text { meeting } \\
\text { Not contacted }\end{array}$ & $\begin{array}{l}\text { Erosion of beaches, especially during storms; toxic waste } \\
\text { buried in offshore sand due to historic industrial activities; } \\
\text { illegal recreational fishing near sewerage outlets }\end{array}$ \\
\hline \multicolumn{4}{|c|}{ Regional (Catalan government) } \\
\hline $\begin{array}{l}\text { Directorate General } \\
\text { of Fisheries }\end{array}$ & Recreational and commercial fisheries; monitoring & $\begin{array}{l}\text { Contacted: } \\
\text { attended first } \\
\text { meeting }\end{array}$ & $\begin{array}{l}\text { Municipal solid waste in artisanal fishing zones; effect of } \\
\text { new coastal infrastructures on water quality; creation of } \\
\text { artificial reefs }\end{array}$ \\
\hline $\begin{array}{l}\text { Catalan Water } \\
\text { Agency }\end{array}$ & $\begin{array}{l}\text { Water management; waste water management; } \\
\text { stormwater collectors planning; river basin planning; } \\
\text { infrastructures; public information; flooding control; } \\
\text { application of Water Framework and Bathing Water } \\
\text { Directives; monitoring }\end{array}$ & $\begin{array}{l}\text { Contacted: } \\
\text { attended all } \\
\text { meetings }\end{array}$ & $\begin{array}{l}\text { Water quality following combined sewer overflows; } \\
\text { efficacy of stormwater collectors related to water quality; } \\
\text { erosion of beaches; jellyfish strandings; compliance with } \\
\text { European Union directives }\end{array}$ \\
\hline \multicolumn{4}{|l|}{ Local (Barcelona) } \\
\hline $\begin{array}{l}\text { Department of Parks } \\
\text { and Gardens }\end{array}$ & $\begin{array}{l}\text { Beaches maintenance; end user satisfaction; water } \\
\text { quality monitoring; noise control; licensing of } \\
\text { businesses on the beach; public information; waste } \\
\text { collection }\end{array}$ & $\begin{array}{l}\text { Contacted: } \\
\text { attended first } \\
\text { and fourth } \\
\text { meeting }\end{array}$ & $\begin{array}{l}\text { Water quality following combined sewer overflows; } \\
\text { erosion of beaches; jellyfish strandings; compliance with } \\
\text { European Union directives }\end{array}$ \\
\hline $\begin{array}{l}\text { CLABSA } \dagger \text { (Private } \\
\text { sector) }\end{array}$ & $\begin{array}{l}\text { Sewage management and monitoring; stormwater } \\
\text { collectors management }\end{array}$ & $\begin{array}{l}\text { Contacted: } \\
\text { attended the } \\
\text { fourth } \\
\text { meeting and a } \\
\text { post-project } \\
\text { meeting }\end{array}$ & \\
\hline Recreational Harbor & Licensing; waste management within the harbor & $\begin{array}{l}\text { Contacted: } \\
\text { attended first } \\
\text { meeting }\end{array}$ & $\begin{array}{l}\text { Anti-fouling paint; gasoline spills; effect of River Besòs } \\
\text { storm plume; dredging entrance of port; pollution from } \\
\text { port restaurants and bars }\end{array}$ \\
\hline $\begin{array}{l}\text { EMSSA } \ddagger \text { (Private } \\
\text { sector) }\end{array}$ & River Besòs wastewater treatment plant management & $\begin{array}{l}\text { Contacted: no } \\
\text { reply }\end{array}$ & \\
\hline
\end{tabular}

$\uparrow$ CLABSA: Clavegueram de Barcelona, Sociedad Anónima

† EMSSA: Empresa Metropolitana de Sanejament, Sociedad Anónima

Mediterranean Sea coast (Nicholls and Hoozemans 1996), but there has been little analysis of the possible interactions between the ecological, social, and economic components of the social-ecological system. This made Barcelona an interesting study site in which the capabilities of the SAF could be explored in a representative case of urban beaches on the Mediterranean Sea.

\section{METHODS AND RESULTS}

\section{System design: stakeholder identification and participation in defining the system and the issue}

Adaptive management and the Systems Approach Framework share the common philosophy that the process of management should be both social and scientific, and should involve stakeholders in constructing conceptual models (mathematical or otherwise) to improve the understanding of the system
(Resilience Alliance 2002, Chapin et al. 2009); to use different knowledge systems, including both local and scientific; to integrate various disciplines; and during decision-making and deliberations with stakeholders. AM advocates "social network analysis" (Resilience Alliance 2007, Ernstson et al. 2008), and SAF suggests, although does not necessarily require, the use of stakeholder mapping. Both techniques are employed to understand the existence of social relations, how they relate to each other, and the power structure within and between them (Prell et al. 2009, Reed et al. 2009).

Following a brief examination of the system, it became evident that the stakeholder consensus view was to conserve the information functions of the ecological system, specifically the recreational, aesthetic, and cultural services (See Discussion for further analysis). 
In implementing the SAF methodology to the study site application of the urban beaches of Barcelona, a provisional institutional and stakeholder map was formed. At the time, there was no known existing forum for these stakeholders to interact at the city scale, so we created one to meet the objectives of our SAF application.

During the initial discussions about who would be invited to the first meeting, there was disagreement among the scientific group as to whether the more "conflictive" stakeholders (such as environmental nongovernmental organizations, surfers, local residents) should be included or not. The other stakeholders with more power in decision-making processes (public administrators) might have objected to their inclusion and therefore chosen not to attend the meeting, effectively ending the process before it started. It was decided that the potentially more conflictive stakeholders would not be invited initially but possibly would be included later following consultation with the other stakeholders. Public administrators would, in general, already be aware of the concerns of the more conflictive stakeholders. Table 1 provides a list of the stakeholders, their responsibilities, the meetings each one attended, and the issues they raised during the first stakeholder meeting.

During the first meeting, it became clear that a common issue of interest to most stakeholders was water quality, particularly following combined sewer overflow events. The interest in this issue arose partly from compliance obligations to various European Union directives (Directive 2000/60/EC, Directive 2006/7/EC), and partly because of a connection to the stakeholders' work responsibilities (e.g., decline in tourism at the recreational harbor caused by poor local environmental conditions).

The research team determined that it had sufficient data and expertise to analyze this problem, so it was decided that the issue to be investigated would be "the effects of changes in water quality on the aesthetic and recreational services of the Barcelona beaches". Water quality was defined in terms of aquatic pathogenic organisms and water clarity, using fecal coliforms and suspended matter as indicators, respectively. Apart from combined sewer overflow events, other important factors that affect coastal water quality include one or more of the following factors: re-suspension of sediment caused by waves, inputs from local rivers, inputs from the local wastewater treatment plant, and flushing rates of the beaches. Neither the stakeholders nor the scientists viewed phytoplankton as having a significant effect on water clarity. Existing mitigation methods include the output of the wastewater treatment plant at a distance of $3 \mathrm{~km}$ from the beaches (whereas before it was much nearer) and the use of stormwater collectors to reduce combined sewer overflows.

Similarly to AM, the SAF recommends making a preliminary mental or conceptual model of the issue in order to identify the main structures and relationships among them, as well as the relevant scales to be analyzed. Following stakeholder deliberation and expert consultation, all the relevant elements and links within and between the ecological, social, and economic components of the issue were mapped as a conceptual model. The stakeholders were encouraged to participate in this process in order to create a shared vision of the issue, its causes and drivers, and possible future scenarios, and to provide any data necessary to calibrate the mathematical model. Fig. 2 illustrates this shared vision of the system as agreed by the research team with the stakeholders. This conceptual model was the same one presented to the Commission on Coastal Affairs during the output step.

During this process, it became evident that a certain stakeholder held important information regarding the accurate functioning of part of the system but did not want to participate in the application of the methodology. There were a number of possible reasons for this, including lack of available time, resources, personnel, or interest, but the most likely reason was that the stakeholder, a private contractor for the regional government, could lose revenue due to the possible conclusions of the methodology. The lack of involvement of this key stakeholder resulted in an oversimplified representation being used in the mathematical model. This has obvious implications for the veracity of the model and therefore also its credibility among other stakeholders. Although the general structure of the model and key variables would remain the same, the inclusion of the missing information, when available, could later improve the model. It should be noted that until the missing information is included in the model, it is unknown whether the overall conclusions would be different.

\section{System formulation and system appraisal: developing the mathematical model from the conceptual model, and exploring outputs and scenarios}

The SAF urges the use of a participatory modeling approach in which stakeholders play a role in certain aspects of system formulation, such as the advising of indicators and relevance of scenarios. However, in our case study this was not entirely possible due to a combination of a tight project schedule and time, resources, and personnel constraints of the stakeholders. However, this does not imply a lack of interest in the model on behalf of the stakeholders. They offered data for parameterization and validation, and advice in the conceptual design and mathematical model, and were keen to use the model following its completion (during the first iteration of the SAF). Similarly, stakeholders (Catalan Water Agency, Department of Parks and Gardens) commented that for those involved exclusively in maintaining the ecological aspects of the system, it was interesting to see the possible socioeconomic impact of the ecological disturbance and the feedback effect on the socioeconomic component. 
Fig. 2. Conceptual model of the system. The model was refined from the first meeting to the third, and includes those aspects that arose during the whole process of modeling. The format was suggested by the Catalan Water Agency during the second meeting. A simple PowerPoint diagram was chosen as a familiar way of visualizing information for all the stakeholders.

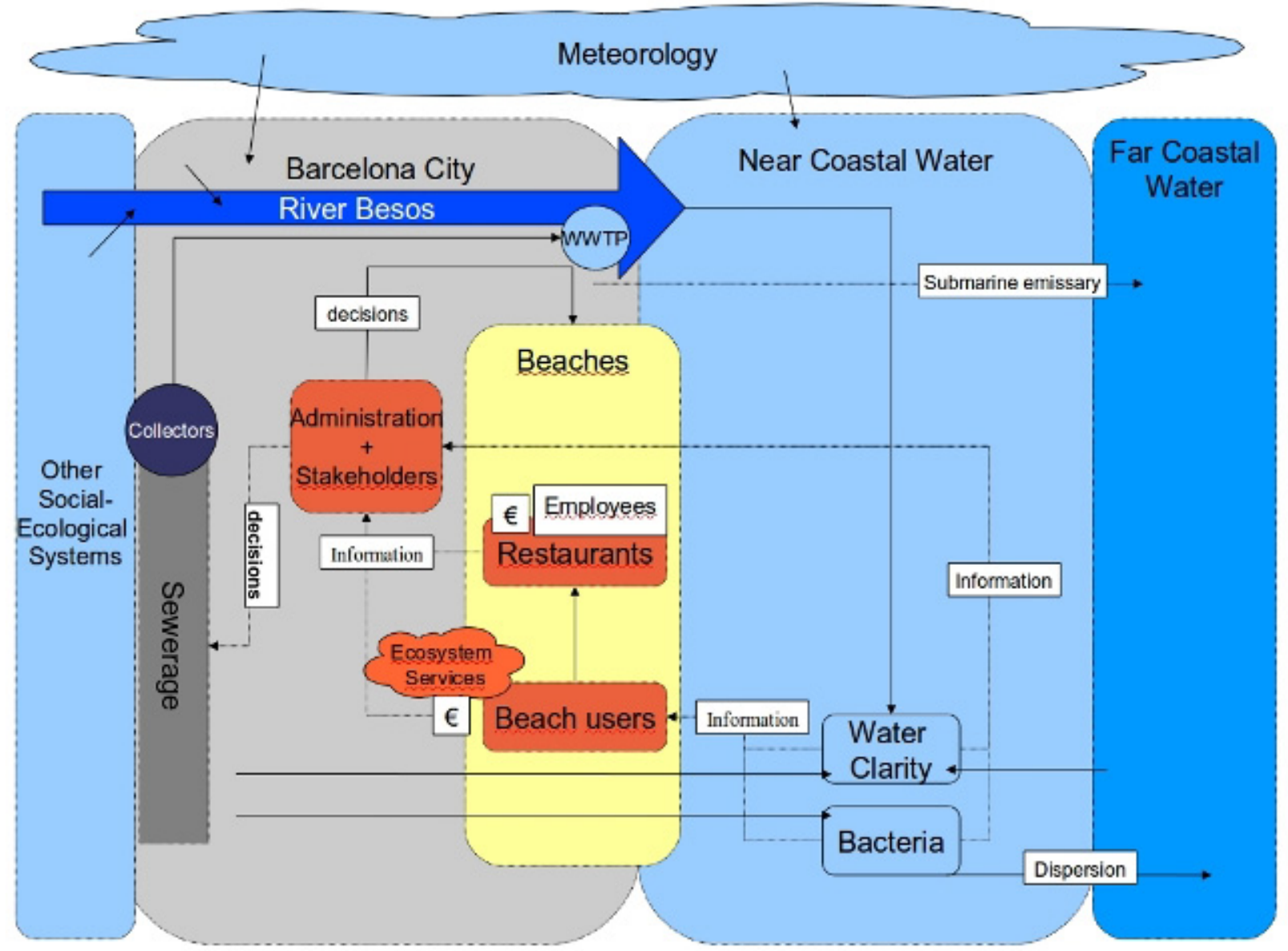

Due to the complexity of most issues regarding ecological, social, and economic interactions in the coastal zone, the SAF methodology recommends construction of a systems dynamic model. Similar to AM, the new knowledge disclosed by the model must be understandable by all stakeholders and help in consensus building. Constructing the model hierarchically allows each user to investigate each component to the precision they require or can understand. The amenability of the model is paramount to its acceptance by the stakeholders without which, it is liable to suffer "black box" model syndrome. The purpose of the model simulations is to help increase the understanding of the functioning of the system. Due to time constraints, the scenarios were created following internal discussion within the scientific team instead of as a result of stakeholder consultation, as is recommended by the SAF. However, in later discussions, the stakeholders valued the scenarios as "reasonable and interesting".
In the following section, some of the main findings revealed during the model construction process are presented. These sections highlight comparisons between the SAF and AM, and demonstrate the lessons learned in applying the SAF to our case study.

\section{Understanding the importance of various temporal scales}

When constructing a mathematical model, it is necessary to choose both a spatial and temporal scale. However, it is important to remember that the system itself is in a nested hierarchy of other systems that are all evolving through their own adaptive cycle (Holling and Gunderson 2001). The SAF does not attempt to model the "panarchy" of nested adaptive cycles, but during system formulation, the importance of the differences in scale between and within components becomes evident. In our study site application, there is a clear disconnect between economic effects (measured in money) and mitigation scenarios and the effect these would have on the 
ecological component (i.e., reducing bacteria and/or turbidity) and on the social component. The construction of stormwater collectors is an expensive (and timely) process, and any possible real money recuperation of these costs would be lengthy and probably not possible. However, these costs might be justified by nonmarket valuation techniques, discussed in Scenario analysis of the stormwater collectors.

There is an inherent conflict between reducing beach regeneration caused by storm-related erosion (by constructing breakwaters) and increasing the flushing rate of the beaches, which is a problem directly related to temporal scale. On a daily basis, it would be advantageous to maximize the flushing rate to reduce water pollution from combined sewer overflow events (no breakwaters). However, on a yearly scale, the lack of breakwaters would leave the beaches susceptible to stormrelated erosion. The model is set at a scale that includes only the daily changes to the system, but this conflict became evident during system formulation. Future iterations of the SAF process in this study site application could easily be adapted to include such conflicts.

\section{Identification of the feedback loops}

A crucial aspect of dynamic models is feedback loops, which, depending on whether they are positive or negative, can push the state away from or towards equilibrium or its attractor, possibly resulting in regime change. Modeling helps identify these loops. A significant negative feedback loop in our case study, where the system acts to oppose changes to the input of the system, is the recreational appeal of the beaches and its carrying capacity (Fig. 3).

\section{Identifying missing key environmental and sociological data}

A benefit of creating models, whether mathematical or conceptual, is that the importance and availability of key data can be identified, and it can be determined if they are available and are of a sufficient resolution (temporal or spatial). The collection of data is a costly process in terms of both resources and time. Having constructed and tested a model, it becomes evident which data have the most significant impact in the functioning of the system, and therefore which data would improve or validate the model's efficacy. The SAF advocates implementing continuous iterations of the methodology so that the model is continually adapted to the evolving reality and knowledge attained. This allows time for the key missing data to be collected, collated, and analyzed. It should be noted that in this study case, time constraints limited the application of the methodology to a single iteration.

During the formulation of the model for our case study, we became aware of key, unavailable, or incomplete data sets. Within the ecological component, there were not sufficient data to compare with the model output to provide comprehensive validation and verification. The available data sets for both bacteria and turbidity (equivalent to suspended
Fig. 3. Feedback loop in beach visitors. Even if water quality improved and the recreational appeal of the beach greatly increased, this would not necessarily result in a greater number of beach users because the beach would already be close to its recreational carrying capacity, especially during the summer months. (Recreational carrying capacity is defined as the number of beach visitors that are physically able to occupy the beach, limited by behavioral norms such as the distance at which the visitors are prepared to sit from each other [De Ruyck et al. 1997]). Conversely, if the recreational appeal decreased due to adverse water quality conditions, the number of visitors would not necessarily decrease significantly. People prefer less crowded beaches; therefore, as the number of visitors decreases due to poor water quality conditions, other people would likely visit because the beach would become less crowded. There is a possible feedback from water quality of the beaches to increased visitors to the local bars and restaurants (indicated by a dotted line), but we did not include this in our model due to a lack of available data.

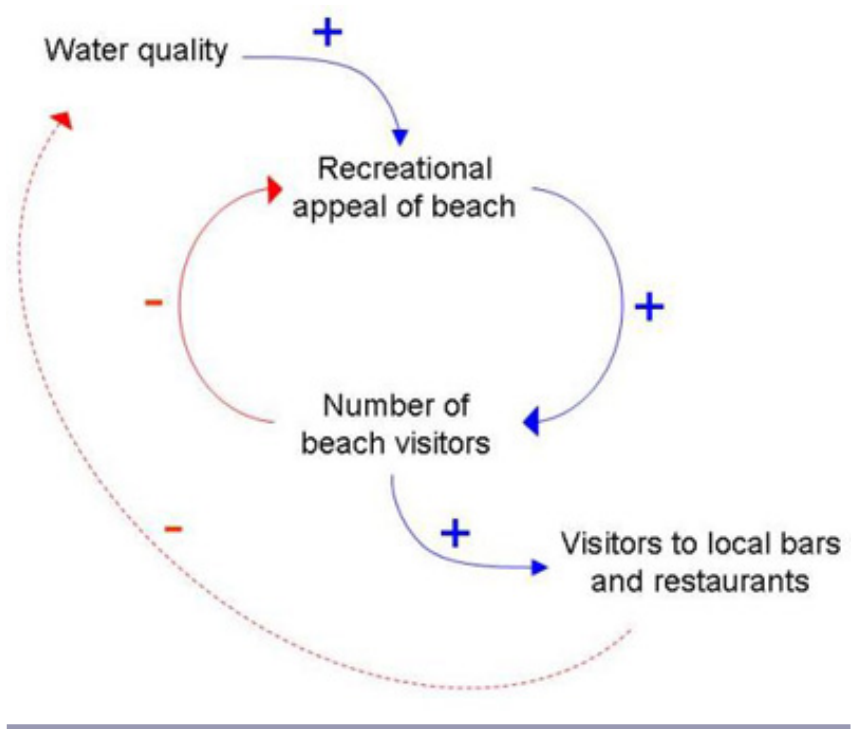

matter) exist only at a maximum temporal resolution of biweekly and only during the summer months. The sampling rarely coincided with storms; thus, many of the peaks assumed to be produced during combined sewer overflow events were not recorded. Given a more complete set of observed values with which the model could be parameterized and verified, there would possibly be a need for a more complete set of other data regarding the ecological component of the model, such as river flow and amount of suspended matter and bacteria; a more accurate functioning of the sewerage and stormwater collector system; greater detail regarding suspended matter and bacteria during combined sewer overflow events; and further studies regarding the flushing rate of the beaches. 
A key connection between the ecological and social-economic components of the model is the change in recreational appeal of the beach. Recreational appeal is dependent on various events, such as beach closure due to bacteria limits being exceeded, and discolored or turbid water. Because insufficient data exist for this parameter, the model included a sliding scale in which the average beach user's susceptibility to adverse conditions could be modified from "none" to "very high". The numeric value for "very high" was estimated by the model's authors, although they conceded it could indeed be greater, however, improbable. This key link between the ecologic and social-economic component was deemed to be significant by the stakeholders (which is why they chose this particular issue during the first meeting); therefore, further analysis would be a crucial step in clarifying if this really is a significant issue or not. Understanding the magnitude of this connection is necessary for accurate assessment of cost-benefit analysis under the various scenarios.

\section{Scenario analysis of the stormwater collectors}

Analysis of the stormwater collector scenarios revealed that both increasing the capacity and reducing the direct runoff of the stormwater collectors could reduce both suspended matter and to a greater extent, bacteria, thereby reducing the number of beach closures by at least half (Table 2). Just increasing the collector capacity (but not reducing the direct runoff) would not decrease the number of days in which bacteria limits were exceeded or high concentrations of suspended matter occurred. A more effective policy would be to decrease the percent of combined sewer overflow runoff that is released directly into the coastal water without being directed towards the stormwater collectors. However, this option might not be physically or politically possible given that the primary objective of the stormwater collectors is to prevent flooding within the city - the quality of the coastal water is a secondary concern.

During stakeholder deliberations, the economic effect of perturbations to the system was requested as an output of the model. However, most clients of the surrounding local bars and restaurants do not originate from the beach. Although their motivation for visiting these bars is connected to the recreational and aesthetic qualities of the beach, it is not directly related to the quality of the water. There is a connection between the number of people who visit the beach (influenced by the quality of the water) and then attend a local bar or a restaurant; however, it is estimated to be small, according to surveys carried out by the research team-about five percent of bar and restaurant users come from the beach. Therefore, the real money influences of changes to water quality are relatively small, but by using nonmarket valuation methodologies, a broader version of "economic value" can be attained. The model incorporates a dynamic block that calculates an economic value for the information services of the beach based on the number of visitors and where they originate from (the travel-cost method). This type of valuation is a positive step in including nonmarket values in an eventual cost and benefits accountability, which is rarely included in economic assessments (Ward and Beal 2000). Through the modeling process and stakeholder deliberation, desired outputs such as these can be requested and incorporated into the model. Stakeholders commented that understanding the economic magnitude of changes to ecological quality and its dependence on users' perceptions both helped them understand the system more clearly. A conclusion of the scenario analysis revealed that investment in additional stormwater collectors would have little effect on water quality, and thus a small impact on the monetary value of ecosystem services (Table 2).

In the case of the construction of additional stormwater collectors (and assuming that users' perception with regard to water quality is very high), the maximum degree of change in monetary benefits (to the local bars and restaurants) would be in the order of tens of thousands of Euros per year. This is relatively insignificant when compared to the cost of constructing additional stormwater collectors. Similarly, there is not much economic difference when comparing the nonmarket benefits of constructing additional stormwater collectors to their cost (Table 2).

\section{System output: presentation of the model, and deliberation of the results by stakeholders}

The SAF methodology does not intend to supply the "correct" answer to an issue or problem-it merely provides the stakeholders with a base from which to structure the debate. The model is just a tool that can provide further information, highlight complex processes, and clarify doubts. The scientists should not decide policy or make managerial decisions because this is the role of the stakeholders and policy makers, but they should be available to explain the implication of the model as well as its veracity and validity.

At the beginning of implementation of the SAF, an ad hoc forum was created for the relevant stakeholders to debate issues regarding the littoral areas of Barcelona. But due to time, resource, and personnel constraints, participation was less than exemplary. Towards the end of the SAF implementation, the scientific team discovered the existence of a regular organized forum between coastal stakeholders from all Catalonia (not just the local scale of Barcelona), the Commission of Coastal Affairs. The scientific team presented both the SAF methodology and the initial results of the model and their implication, as previously discussed in System formulation and system appraisal. A stakeholder who had previously declined (or ignored) the initial ad hoc forum attended this forum, and following the presentation, expressed interest in participating further in the process to help improve the model, possibly by supplying data and information. 
Table 2. Stormwater collector scenarios. Scenario analysis is related to changes in operation of the stormwater collectors. The model operator (stakeholder) has the option of selecting two variables related to the sewerage system (capacity and direct runoff), as well as the sensitivity of beach users to changes in water quality (turbidity and runoff). Because this sensitivity is currently unknown, only the two extremes are shown in the table: none and high (both to bacteria and turbidity). The two extremes demonstrate the maximum possible difference to both the non-market and market value of the beaches for each scenario. The approximate cost of constructing the stormwater collectors for each scenario is included for comparison. It should also be noted that the number of turbid days is the same for both the "current" and "planned" scenarios because although increasing stormwater collector capacity does not affect "low" turbidity, it does affect "high" turbidity (although only by a small degree).

\begin{tabular}{|c|c|c|c|c|c|c|c|c|c|c|c|}
\hline \multirow[b]{2}{*}{$\begin{array}{l}\text { Variables/ } \\
\text { Indicators }\end{array}$} & \multirow[b]{2}{*}{ Units and details } & \multicolumn{10}{|c|}{ Stormwater Collector Scenarios } \\
\hline & & \multicolumn{2}{|c|}{$\begin{array}{l}\text { No collectors } \\
\text { (simulated) }\end{array}$} & \multicolumn{2}{|c|}{ Current } & \multicolumn{2}{|c|}{$\begin{array}{l}\text { Current with } \\
\text { improved runoff } \\
\text { (simulated) }\end{array}$} & \multicolumn{2}{|c|}{$\begin{array}{c}\text { Planned } \\
\text { (simulated) }\end{array}$} & \multicolumn{2}{|c|}{$\begin{array}{l}\text { Planned with } \\
\text { improved } \\
\text { runoff } \\
\text { (simulated) } \\
\end{array}$} \\
\hline \multirow[t]{2}{*}{ Sewerage system } & $\begin{array}{l}\text { Capacity stormwater } \\
\text { collectors (Gigaliter) }\end{array}$ & \multicolumn{2}{|c|}{0} & \multicolumn{2}{|c|}{0.52} & \multicolumn{2}{|c|}{0.52} & \multicolumn{2}{|c|}{1.5} & \multicolumn{2}{|c|}{1.5} \\
\hline & $\begin{array}{l}\text { Runoff direct to coastal water } \\
(\%)\end{array}$ & \multicolumn{2}{|c|}{100} & \multicolumn{2}{|c|}{50} & \multicolumn{2}{|c|}{0} & \multicolumn{2}{|c|}{50} & \multicolumn{2}{|c|}{0} \\
\hline Bacteria & $\begin{array}{l}\text { Number of days in the year in } \\
\text { which limits are exceeded } \\
\text { during the bathing season } \dagger\end{array}$ & \multicolumn{2}{|c|}{7.17} & \multicolumn{2}{|c|}{3.88} & \multicolumn{2}{|c|}{2.58} & \multicolumn{2}{|c|}{3.63} & \multicolumn{2}{|c|}{1.42} \\
\hline \multirow[t]{2}{*}{ Turbidity } & $\begin{array}{l}\text { Number of "turbid" days } \\
\text { during the bathing season } \dagger\end{array}$ & \multicolumn{2}{|c|}{19.21} & \multicolumn{2}{|c|}{15.75} & \multicolumn{2}{|c|}{11.29} & \multicolumn{2}{|c|}{15.75} & \multicolumn{2}{|c|}{8.08} \\
\hline & $\begin{array}{l}\text { Number of "high turbidity" } \\
\text { days during the bathing } \\
\text { season } \dagger\end{array}$ & \multicolumn{2}{|c|}{1.29} & \multicolumn{2}{|c|}{0.75} & \multicolumn{2}{|c|}{0.58} & \multicolumn{2}{|c|}{0.71} & \multicolumn{2}{|c|}{0.42} \\
\hline $\begin{array}{l}\text { Beach user } \\
\text { sensitivity }\end{array}$ & $\begin{array}{l}\text { Beach user sensitivity to } \\
\text { bacteria and turbidity }\end{array}$ & none & high & none & high & none & high & none & high & none & high \\
\hline Beach users & Visitors per year (millions) & 6.36 & 4.85 & 6.36 & 5.26 & 6.36 & 5.41 & 6.36 & 5.33 & 6.36 & 5.69 \\
\hline Non-market value & $\begin{array}{l}\text { Travel cost evaluation per } \\
\text { year ( } € \text { millions) }\end{array}$ & 16.03 & 12.22 & 16.03 & 13.25 & 16.03 & 13.64 & 16.03 & 13.43 & 16.03 & 14.33 \\
\hline Market value & $\begin{array}{l}\text { Revenue from bars and } \\
\text { restaurants per year } \\
\text { (€millions) }\end{array}$ & 29.36 & 29.32 & 29.36 & 29.33 & 29.36 & 29.33 & 29.36 & 29.33 & 29.36 & 29.34 \\
\hline $\begin{array}{l}\text { Cost stormwater } \\
\text { collectors }\end{array}$ & $\begin{array}{l}\text { Approximate construction } \\
\text { costs per scenario (€millions) }\end{array}$ & c & & 15 & & & & & & & \\
\hline
\end{tabular}

$\dagger$ The bathing season is from May until September, inclusive. The value for number of days is calculated from the annual average of a 5-year forecast period.

This entire process highlights an important aspect of participatory management. It demonstrates that a deficit in social capital (OECD 2001, Ostrom and Ahn 2003) can seriously deter any participatory management process. Even with pre-existing forums, they need to be at the correct scale for the chosen issue for the process to function adequately. However, for social capital to be built, confidence between the stakeholders needs to increase. The SAF methodology offers an opportunity for this to occur. Through continuous iterations of the SAF, the stakeholders are likely to grow more confident with each other and observe the benefits in participation in the process. Increasing social capital is a lengthy process and cannot be achieved immediately, so it is not surprising that in our case study, the benefits started to appear only towards the end of the project, about three years after its initiation. No management decisions regarding the 
stormwater collectors or other scenarios presented were made following the final stakeholder meeting. However, the application of the SAF demonstrated its ability to create and maintain social capital, which could be beneficial for future collaboration.

\section{DISCUSSION}

\section{Comparing the Systems Approach Framework and adaptive management}

The SAF could generally be classed as similar to a passive AM approach (Holling 1978, Walters 1986, Holling and Meffe 1996, Chapin et al. 2009), although this depends on the system in question, the stakeholders involved, their vision of the social-ecological system, and its associated issues. Passive AM uses whatever knowledge and information is available to improve the decision-making process. On the other hand, active AM tests the real system, pushing it to (ecological) limits in ways that would not normally be tried, thus providing learning about possible phase changes and a more complete understanding of the social-ecological system. Often, as in our case study, the objective of most policy makers and stakeholders is to maintain the social-ecological system in its current phase and not try to push it to another.

Most procedural components of AM are also advanced by the SAF methodology (Table 3). However, it should be noted that there is not always a direct one-to-one correlation; thus, some components of AM are referred to in more than one SAF "step". This is not surprising given that we are comparing a step-by-step methodological guide (SAF) against a tool for management with generalized recommendations (AM). There are two components of AM that are not explicitly recommended by the SAF ("Encourage the formation of new institutions and strategies" and "Enhance institutional flexibility"), but neither does the SAF discourage them.

Conversely, there are no obvious SAF steps or tasks that could be considered outside of, or contrary to, the recommendations of AM. However, the SAF is more specific in its methodology - for example, in its use of General Systems Theory as the foundation for modeling, and in recommending software that can be easily used by layperson stakeholders. Both the SAF and $\mathrm{AM}$ recommend considering the issue across different temporal and spatial scales. However, within the SAF, a specific scale has to be chosen in order to create a model, although this could change over additional iterations of a given application. AM does not specify exactly how to confront the difficulties involved in creating a computer model across various temporal and spatial scales.

\section{The application of the Systems Approach Framework in Barcelona}

Table 3 also outlines the most important steps in applying the SAF to our case study and how we deviated from the recommended methodology. There were key problems involved in the application, such as failing to identify existing stakeholder forums. This might have saved considerable time in trying to construct a separate forum where one key stakeholder initially chose not to attend. Had we known about the pre-existing forum (which this stakeholder attends), progress would have been quicker regarding both construction of the model and the deliberation process.

Another significant problem encountered involved constructing the model with a lack of information (regarding the correct functioning of the sewerage and stormwater collectors) and a lack of data for calibration and verification. The software used was beneficial in constructing a model that the stakeholders could both easily understand (due to its hierarchical structure) and manipulate (drop-down menus for running various scenarios). To some extent, this diminished the "black box syndrome" that many models suffer, and encouraged the stakeholders to further engage with the model output. We emphasized the uncertainty in the model output but were confident that the orders of magnitude were correct. Comparison with other economic valuation studies had revealed similar results (Ceballos 2008, Brenner et al. 2010).

Many of the processes considered to be vital procedural components of AM (Resilience Alliance 2007) are also advocated within the SAF. However, in our case study, we determined that for these processes to be effectively applied, there needs to be adequate social capital, which can take time to build if it does not already exist. As demonstrated in our case study, the SAF can advance the formation of such relevant networks and institutions in which social capital can burgeon. It is probable that in further iterations of the $\mathrm{SAF}$, the processes advocated by AM would be developed more comprehensively.

\section{Speculation}

There are a number of subtle differences between the SAF and $\mathrm{AM}$ in terms of the emphasis of objectives and procedures, which are not highlighted in Table 3 because they are more speculative. For example, in the SAF, the process starts with scientists who choose a set of stakeholders and together they investigate an issue by choosing the relevant scale together. On the other hand, AM has little to say about how the process starts or whether it should focus on just one management issue or model the entire ecosystem. Because of this, it could be argued that the SAF puts greater emphasis on solving individual issues, decision-making processes, and sustainability, whereas AM puts greater emphasis on sustainability, resilience (passive $\mathrm{AM}$ ), and testing and learning from the ecosystem (active AM).

The current phase regime in Barcelona is one where typical coastline ecosystem services such as food production and fish nurseries have decreased, and in their place information services such as recreation and aesthetic appeal are favored. This has been implicitly decided by the city's residents, although they may be unaware of the large costs (in energy, 
Table 3. Comparison of the Systems Approach Framework (SAF) and adaptive management: application of SAF to Barcelona.

\begin{tabular}{|c|c|c|}
\hline $\begin{array}{c}\text { Systems Approach } \\
\text { Framework } \dagger \\
(\mathrm{SAF})\end{array}$ & Adaptive management $\ddagger$ & $\begin{array}{c}\text { Barcelona case study } \\
\text { (How the SAF was applied) }\end{array}$ \\
\hline
\end{tabular}

Comments

(Deviation from

recommended steps and difficulties encountered)
The aim is to improve ecological sustainability, economic efficiency, and social equity - similar to "passive" adaptive management

\begin{tabular}{ll}
\hline \multicolumn{1}{c}{ Steps } & \multicolumn{1}{c}{ Tasks } \\
\hline System & Identify \\
design & stakeholders; \\
& identify \\
& issues; define \\
& "virtual" \\
& system, \\
& structure, and \\
& functions; set \\
& boundaries; \\
& conceptual \\
& modeling
\end{tabular}

System Construct formulation mathematical and model, system scenarios; appraisal parameterize; validate; choose indicators; assess relevance for stakeholders; interpret results

System Present results Use of embodied output to stakeholders; organize information; deliberate
Can be either "active" or "passive" adaptive management
Procedural components

Inclusion of all relevant
stakeholders; creation and maintenance of political openness; social and scientific process

Consideration of appropriate temporal and spatial scales; use of computer models to build synthesis and an embodied ecological consensus ecological consensus to evaluate strategic alternatives; use of computer models to build synthesis and an embodied ecological consensus; communication of alternatives to political arena for negotiation; inclusion of all relevant stakeholders; creation and maintenance of political openness; social and scientific process
Following stakeholder mapping (Table 1), invitations were sent to the administrative bodies from the three main scales of responsibility over the Barcelona beaches (local, regional, and national). The first meeting was held on 11 October 2007. An issue was agreed upon between the five stakeholders and the ICMCSIC $§$ research team involved in SPICOSA|: "the effects of changes in water quality on the aesthetic and recreational services of the Barcelona beaches", and a first draft of the conceptual model was constructed.

A hierarchical model which included ecological, social, and economic variables was constructed, and the key indicators were water clarity, bacteria concentration, beach user frequentation, and market and non-market valuation of aesthetic and recreational services. A second stakeholder meeting was held on 26 February 2009. The primary scenarios identified as relevant for stakeholders were related to changes in stormwater collector capacity and functioning. Additional scenarios included changes in wastewater treatment plant operational states, river flows and concentrations of bacteria and suspended matter, precipitation, and flushing rates of the beaches.

Results were presented twice, first in a private meeting held on 10 March 2010 with the Catalan Water Agency. Shortly afterwards on 23 March 2010, the results and conclusions were presented to the Commission of Coastal Affairs (a preexisting forum where coastal issues are discussed at the regional level). There was no time for deliberation, but a few stakeholders approached us afterwards regarding the conclusion of the model.

Additionally, the key stakeholder who had declined to attend our previous meetings (but was present here) was now keen to share their time, data, and expertise with us, given that the model produced results that were contrary to their economics interests.
Following an agreement between the research team, the stakeholders were selected to maximize representativeness and minimize the likelihood of conflicts. The SAF recommends including a greater representation of stakeholders.

We were unable to obtain key data and information necessary to construct and validate the mathematical model to a rigorous standard. Future iterations of the SAF might yield the time, resources, and cooperation necessary to address these deficiencies.

The forum of the

Commission of Coastal Affairs was discovered late in the application of the SAF, and the fact that it was not identified earlier should be considered a failure of the scientific team. Given the social capital already invested in this commission, it would have been preferable to apply the SAF here rather than creating ad hoc meetings as we did. 
Encourage the formation

of new institutions and

strategies; enhancement of

institutional flexibility
The SAF can provide policy strategies as options but does not explicitly recommend these components of adaptive management.

$\dagger$ SPICOSA (2011c)

$\ddagger$ Resilience Alliance (2002)

$\S$ ICM: Institut de Ciènces del Mar; CSIC: Consejo Superior de Investigaciones Científicas

| Science and Policy Integration for Coastal System Assessment

resources, money, and personnel) involved in maintaining the beaches in their current state. During shocks to the socialecological system (e.g., general economic crisis, increase in price of energy, increased storm activity and erosion caused by climate change, sea-level rise), there might be less impetus by the public to continue with this sort of investment, and the beaches would slowly transform to a regime that does not require a constant input of exosomatic energy and resources in order to be perpetuated. Any type of resilience management has to examine the issue explored in this paper through the lens of this implication. The application of this first iteration of the SAF to the case study of Barcelona sufficiently explores various scenarios as requested by the stakeholders but from the perspective of a reduced temporal scale. Through further iterations, it would be possible to include shocks to examine the resilience of the social-ecological system over a larger temporal scale, thus approaching the objectives of AM.

\section{The future of the Systems Approach Framework}

It is difficult to suggest improvements to the design of the SAF because it is an open methodological framework. The most technical aspects of the methodology, such as stakeholder interaction and construction of the model, are not rigidly defined, and are therefore open to a degree of interpretation. This has the obvious drawback of requiring experts to aid in the process but leaves it sufficiently open so that the methodology can be applied to a diverse set of issues across varying cultural and political communities.

Similar to any social policy or strategy, it is difficult to predict the future trajectory that the SAF will take. As a tool for management, it requires significant time, resources, and personnel. For the process to run smoothly, there needs to be trans-disciplinary scientists or at least scientists capable of understanding and communicating outside of their own specialization, modelers who can interact with all disciplines and are familiar with general systems theory, and social scientists trained in stakeholder deliberation. The true limitations might lie in attempting to confront the existing power structure of institutions and organizations by convincing them to engage in the process.
Within the SPICOSA project, the process was largely funded by the European Union (by the Framework Programme for Research and Technological Development). However, such research funds cannot subsidize all future implementations of the SAF-there has to be shared responsibility between science and policy. Obviously, for the policy makers to invest in the process and justify the expenditure at the political level, they would have to see the benefits either from previous implementations of the SAF or from envisaging the possible advantages of future iterations.

The SAF is a well-structured methodology for cases where a mathematical model is both relevant and feasible with regards to both knowledge of the functioning of each component of the social-ecological system and the availability of data, resources, and personnel. The SAF should be considered as a useful step-by-step guide for certain contexts, and could either be classified as a nested framework within AM or as a complementary methodology of AM.

Responses to this article can be read online at: http://www.ecologyandsociety.org/voll6/iss4/art28/ responses/

\section{Acknowledgments:}

The authors would like to thank all the stakeholders involved in this experiment, particularly those at the Catalan Water Agency, who were very cooperative and helpful in assisting us throughout the whole process. We would also like to thank the subject editor and the two anonymous reviewers for their concise and constructive comments which helped improve this article.

\section{LITERATURE CITED}

Bas, C., E. Morales, and M. Rubió. 1955. La pesca en España y Cataluña. Instituto de Investigaciones Pesqueras, CSIC, Barcelona, Spain.

Brenner, J., J. A. Jiménez, R. Sarda, and A. Garola. 2010. An assessment of the non-market value of the ecosystem services 
provided by the Catalan coastal zone, Spain. Ocean \& Coastal Management 53(1):27-38. [online] URL: http://dx.doi.org/10 $.1016 /$ j.ocecoaman.2009.10.008

Ceballos, D. 2008. Valoración de un recurso natural. Un caso de comparación entre diferentes alternativas de valoración global. Anales de Economía Aplicada. Número XXII.

Chapin, III, F. S., G. P. Kofinas, and C. Folke, editors. 2009. Principles of ecosystem stewardship: resilience-based natural resource management in a changing world. Springer Science + Business Media, New York, USA. [online] URL: http://ww w.springerlink.com/content/978-0-387-73033-2

\#section=61977\&page $=1$

Checkland, P. B., and J. Scholes. 1990. Soft systems methodology in action. John Wiley and Sons, Chichester, UK.

Costanza, R. 1998. The ecological, economic and social importance of the oceans. Ecological Economics 31(2):199213. [online] URL: http://dx.doi.org/10.1016/S0921-8009(99) $\underline{00079-8}$

Costanza, R., and J. Farley. 2007. Ecological economics of coastal disasters: introduction to the special issue. Ecological Economics 63(2-3):249-253. [online] URL:http://dx.doi.org/ $\underline{10.1016 / j . e c o l e c o n .2007 .03 .002}$

De Ruyck, M. C., A. G. Soares, and A. McLachlan. 1997. Social carrying capacity as a management tool for sandy beaches. Journal of Coastal Research 13(3):822-830. [online] URL: http://www.jstor.org/pss/4298675

Directive 2000/60/EC of the European Parliament and of the Council establishing a framework for community action in the field of water policy. Official Journal of the European Communities L Legis 2000 327:1-73.

Directive 2006/7/EC of the European Parliament and of the Council of 15 February (2006) concerning the management of bathing water quality and repealing Directive 76/160/EEC. Official Journal of the European Union 4.3.2006, L64/37.

Ernstson, H., S. Sörlin, and T. Elmqvist. 2008. Social movements and ecosystem services-the role of social network structure in protecting and managing urban green areas in Stockholm. Ecology and Society 13(2):39. [online] URL: htt p://www.ecologyandsociety.org/vol13/iss2/art39/

European Parliament and Council. 2002. Recommendation of the European Parliament and of the Council of 30 May 2002 concerning the implementation of integrated coastal zone management in Europe (2002/413/EC). OJ L148 06.06.2002 Official Journal of the European Communities 2002:24-7.

Folke, C. 2006. Resilience: the emergence of a perspective for social-ecological systems analyses. Global Environmental Change 16:253-267. [online] URL: http://dx.doi.org/10.1016/ j.gloenvcha.2006.04.002
Folke, C., S. Carpenter, T. Elmqvist, L. Gunderson, C. S. Holling, and B. Walker. 2002. Resilience and sustainable development: building adaptive capacity in a world of transformations. Ambio 31(5):437-440. [online] URL: http:// www.bioone.org/doi/full/10.1579/0044-7447-31.5.437

Folke, C., S. R. Carpenter, B. Walker, M. Scheffer, T. Chapin, and J. Rockström. 2010. Resilience thinking: integrating resilience, adaptability and transformability. Ecology and Society 15(4):20. [online] URL: http://www.ecologyandsociety. org/vol15/iss4/art20/

Gunderson, L. 2008. Adaptive management and integrative assessments. Pages 55-59 in S. E. Jorgensen and B. Fath, editor(s)-in-chief. Encyclopedia of Ecology. Academic Press, Oxford, UK.

Holling, C. S. 1978. Adaptive environmental assessment and management. Wiley, London, UK. Reprinted in 2005 by Blackburn Press, Caldwell, New Jersey, USA.

Holling, C. S. 2001. Understanding the complexity of economic, ecological, and social systems. Ecosystems 4 (5):390-405. [online] URL: http://dx.doi.org/10.1007/s10021 $\underline{-001-0101-5}$

Holling, C. S., and L. H. Gunderson. 2001. Resilience and adaptive cycles. Pages 25-62 in L. H. Gunderson and C. S. Holling, editors. Panarchy: understanding transformations in human and natural systems. Island Press, Washington D.C., USA.

Holling, C. S., and G. K. Meffe. 1996. Command and control and the pathology of natural resource management. Conservation Biology 10(2):328-337. [online] URL: http://on linelibrary.wiley.com/doi/10.1046/j.1523-1739.1996.10020328. x/abstract

Hopkins, T. S., D. Bailly, and J. G. Støttrup. 2011. A systems approach framework for coastal zones. Ecology and Society 16(4): 25. http://dx.doi.org/10.5751/ES-04553-160425

King, G. 2003. The role of participation in the European demonstration projects in ICZM. Coastal Management 31 (2):137-143. [online] URL: http://dx.doi.org/10.1080/089207 $\underline{50390168354}$

Martinez, M. L., A. Intralawan, G. Vazquez, O. PerezMaqueo, P. Sutton, and R. Landgrave. 2007. The coasts of our world: ecological, economic and social importance. Ecological Economics 63(2-3):254-272. [online] URL: http:/ /www.sciencedirect.com/science/article/pii/S0921800906005465 http://dx.doi.org/10.1016/j.ecolecon.2006.10.022

McKenna, J., and J. A. G. Cooper. 2006. Sacred cows in coastal management. The need for a "cheap and transitory" model. Area 38(4):421-431. [online] URL: http://dx.doi.org/10.1111/ j.1475-4762.2006.00708.x 
Millennium Ecosystem Assessment. 2005a. Ecosystems and human well-being: synthesis. Island Press, Washington, D.C., USA.

Millennium Ecosystem Assessment. 2005b. Coastal systems. Pages 533-536 in Ecosystems and human well-being: current state and trends. Island Press, Washington, D.C., USA.

Nicholls, R. J., and F. M. J. Hoozemans. 1996. The Mediterranean: vulnerability to coastal implications of climate change. Ocean \& Coastal Management 31(2-3):105-132. [online] URL: http://dx.doi.org/10.1016/S0964-5691(96)00037-3

Novoa, M., and J. Alemany. 2005. Evolución de la Costa de Barcelona. Dirección General de Costas. Ministerio de Medio Ambiente, Madrid, Spain.

Organisation for Economic Co-operation and Development (OECD). 2001. The well-being of nations: the role of human and social capital. OECD, Paris, France.

Ostrom, E., and T. K. Ahn. 2003. Foundations of social capital. Edward Elgar Publishing, Cheltenham, UK.

Prell, C., K. Hubacek, and M. Reed. 2009. Stakeholder analysis and social network analysis in natural resources management. Society and Natural Resources 22(6):501-518. http://dx.doi.org/10.1080/08941920802199202

Reed M. S., A. Graves, N. Dandy, H. Posthumus, K. Hubacek, J. Morris, C. Prell, C. H. Quinn, and L. C. Stringer. 2009. Who's in and why? A typology of stakeholder analysis methods for natural resource management. Journal of Environmental Management 90(5):1933-1949. [online] URL: http://www.sciencedirect.com/science/article/pii/S0301479709000024 http://dx.doi.org/10.1016/j.jenvman.2009.01.001

Resilience Alliance. 2002. Adaptive management. [online] URL: (http://www.resalliance.org/index.php/adaptive management )

Resilience Alliance. 2007. Assessing resilience in socialecological systems: a scientists workbook. [online] URL: htt p://www.resalliance.org/3871.php

Roig, E. 1927. La pesca a Catalunya. Noray, Barcelona, Spain.

Science and Policy Integration for Coastal System Assessment (SPICOSA). 2011a. SPICOSA portal. [online] URL: http://w ww.spicosa.eu

Science and Policy Integration for Coastal System Assessment (SPICOSA). 2011b. Systems Approach Framework handbook. [online] URL: http://www.coastal-saf.eu/

Science and Policy Integration for Coastal System Assessment (SPICOSA). 2011c. Online data portal. [online] URL: http:// www.spicosa.eu/dataportal/index.htm)
Tett, P., A. Sandburg, and A. Mette. 2011. Sustaining coastal zone systems. Dunedin Academic Press, Edinburgh, Scotland.

von Bertalanffy, L. 1968. General systems theory: foundations, development, applications. George Braziller, New York, New York, USA. http://dx.doi.org/10.1109/TSMC $\underline{.1974 .4309376}$

Walker, B., S. Carpenter, J. Anderies, N. Abel, G. Cumming, M. Janssen, L. Lebel, J. Norberg, G. D. Peterson, and R. Pritchard. 2002. Resilience management in social-ecological systems: a working hypothesis for a participatory approach. Conservation Ecology 6(1):14. [online] URL: http://www.eco logyandsociety.org/vol6/iss1/art14/

Walters, C. 1986. Adaptive management of renewable resources. MacMillan, New York, New York, USA.

Ward, F. A., and D. J. Beal. 2000. Valuing nature with travel costmodels: a manual.Edward Elgar Publishing, Cheltenham, UK.

Westley, F. 2001. The devil in the dynamics: adaptive management on the front lines. Pages 333-360 in L. H. Gunderson, L. H. and C. S. Holling, editors. Panarchy: understanding transformations in human and natural systems. Island Press, Washington D.C., USA. 